\title{
KANGURU POHON (Dendrolagus sp) POTENSI LOKAL PAPUA SUMBER PANGAN MASA DEPAN
}

\author{
Johan F. Koibur \\ Laboratorium Pengembangan Aneka Ternak \& Satwa, Fakultas Peternakan (FAPET) \\ Universitas Papua (UNIPA) Manokwari, Email:jfkoibur@yahoo.co.id \\ Diajukan: 5 Januari 2018 ; Diterima: 1 Maret 2018
}

\begin{abstract}
Abstrak
Kanguru yang selama ini lebih identik dengan Australia sesungguhnya adalah juga salah satu jenis satwa endemik di Papua, yang telah dikenal dan dimanfaatkan oleh masyarakat di Papua sebagai sumber protein hewani keluarga. Khususnya kanguru pohon (Dendrolagus sp) merupakan jenis mamalia yang terdapat hampir di seluruh wilayah Papua dan di beberapa pulau-pulau kecil di sekitarnya termasuk di kawasan Teluk Cenderawasih dan Kepulauan Raja Ampat. Kanguru pohon memiliki potensi untuk dikembangkan sebagai hewan peliharaan dan sumber protein hewani alterntif karena dapat hidup dan berkembang biak di luar habitat aslinya, memiliki kemampuan beradaptasi dengan lingkungan barunya serta dapat melakukan aktivitas kesehariannya seperti makan, minum, istirahat, bermain dan reproduksi sebagaimana kebiasaannya di alam selama 24 jam. Kanguru Pohon hidup di hutan primer menghuni. Penyebarannya mulai dari permukaan laut sampai dengan ketinggian 4000 meter di atas permukaan laut di daerah hutan tropis. Pemanfaatan kanguru pohon oleh masyarakat merupakan salah satu usaha pengeanekaragaman pangan oleh masyarakat setempat, yaitu proses pemilihan pangan yang tidak tergantung pada satu jenis bahan saja, tetapi terhadap macammacam bahan pangan mulai dari aspek produksi, pengelolaan, distiribusi hingga aspek konsumsi pangan di tingkat rumah tangga.
\end{abstract}

Kata kunci: kanguru pohon, potensi lokal, sumber pangan, Papua

\section{PENDAHULUAN}

Kanguru lebih identik dengan Australia bahkan popularitasnya melebihi ternak-ternak domestikasi seperti sapi, domba, babi dan unggas yang telah mengalami berbagai perkembangan dan tingkatan breed ratusan hingga ribuan tahun silam dengan campur tangan manusia dan teknlogi hingga mencapai parent stock unggulan dari Benua ini. Namun demikian ketika menyebutkan Australia, maka yang pertama kali terlintas adalah Kanguru, mengapa demikian? Karena satwa ini hidup dan berkembang secara luar biasa di Benua tersebut dan diklaim bahwa hanya terdapat di Benua ini dan dijadikan sebagai lambang negaranya, stigma ini bisa dibenarkan oleh karena pemerintah, swasta dan masyarakat Australia mencurahkan perhatian penuh pada satwa ini dengan mengeluarkan regulasi yang memproteksi akan keberadaannya, tetapi juga memberikan ruang, fasilitas dan dana bagi upaya-upaya penelitian, publikasi dan sosialisasi tentang berbagai potensi yang dimiliki Kanguru untuk kepentingan manusia.
Manfaat Kanguru dari berbagai riset yang dilakukan di Australia antara lain di bidang kedokteran (inisiasi menyusui bayi manusia yang baru lahir tanpa bantuan ibunya dan cara mengatasi bayi manusia dengan berat badan lahir rendah) yang kemudian diadopsi menjadi mengasuh bayi ala Kanguru; di bidang Lingkungan dalam kaitannya dengan Global warming (kentut/pengeluaran gas dari perut kanguru ramah lingkungan karena terdapat bakteri khusus pada perut kanguru sehingga gas yang keluar bukan metana) ada gagasan untuk membuat perut ala kanguru pada ternak domestikasi dengan memindahkan bakteri khusus pada kanguru kedalam perut ternak domestikasi. Merujuk pada hasil risetnya banyak ilmuwan menganjurkan rakyat Australia agar mengurangi beternak sapi dan domba, dan makan lebih banyak kanguru. Menurut Peter Ampt dari institut studi lingkungan Universitas New South Wales, daging kanguru hanya mengandung sedikit lemak sedangkan kandungan proteinnya tinggi dan rasanya enak. (ahmadirfan.oggix.org/2008/03/01) 
Papua yang merupakan salah satu provinsi di Indonesia, yang oleh para ilmuwan dikategorikan dalam satu bagian bersama Australia menurut geographic histories, ternyata memiliki beberapa kemiripan pada flora dan fauna khususnya mamalia yang hidup dan berkembang pada kedua wilayah ini (Papua dan Australia) umumnya adalah mamalia berkantung (Makropodidae) diantaranya Dendrolagus, Zaglossus, Phalangeridae, dan Bandikot.

\section{METODE}

Paper ini merupakan suatu review literatur dari berbagai penelitian yang dilakukan di terhadap kanguru pohon berkaitan dengan aspek potensi kanguru sebagai sumber pangan hewani bagi masyarakat. Diharapkan tulisan ini dapat menjadi satu referensi dalam mendorong pengembangan program pemanfaatan hewan lokal dengan tujuan diversifikasi pangan menurut konsep penggunaan berkelanjutan (sustainable use) di Papua.

\section{Sistimatika Kanguru Pohon (Dendrolagus}

$\mathrm{sp)}$
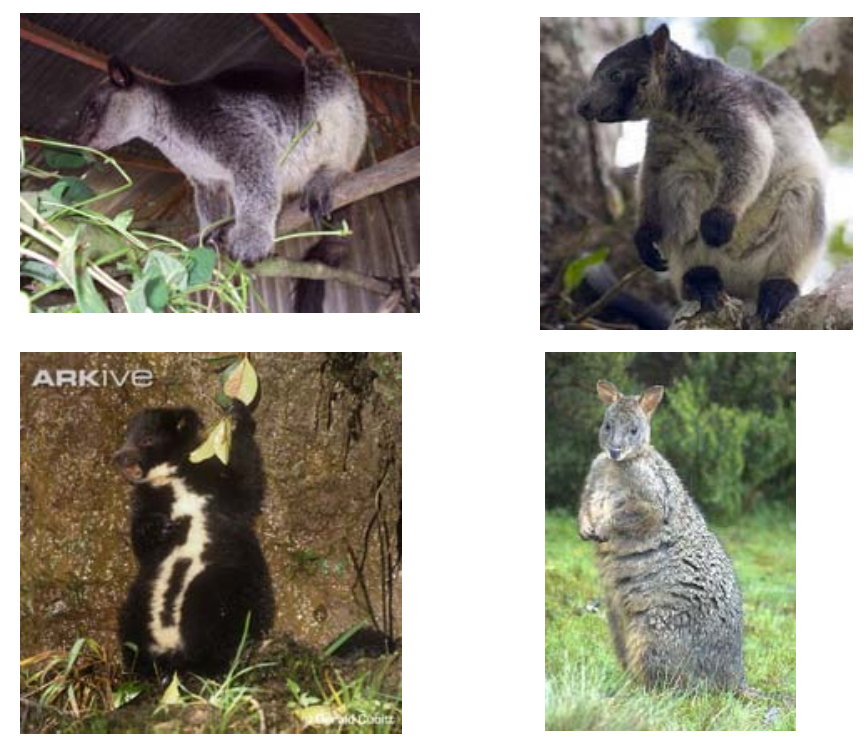

Petocz (1994) mengklasifikasikan Kanguru Pohon sebagai berikut :

Kingdom : Animalia

Phylum : Chordata

Class : Mamalia

Family : Macropodidae

Genus : Dendrolagus

Spesies : D. inustus (kanguru pohon kelabu),

D. ursinus (kanguru pohon hitam/leher putih), D. Dorianus notatus (kanguru pohon doria), D.mbaiso (kanguru pohon coklat), D. spadix (kanguru pohon dataran rendah) dan D. good fellow (kanguru pohon hias)

Khususnya Papua, mamalia yang termasuk pada famili Macropodidae hanya diwakili oleh Kanguru Pohon dan Walabi yang merupakan Marsupialia terbesar. Kanguru Pohon adalah kelompok keluarga Marsupial (binatang berkantung) yang kini paling berkembang. 


\section{Habitat dan Penyebaran Kanguru Pohon di Papua}

Kanguru pohon hidup hampir di seluruh wilayah Papua (daratan dan pulau) dengan menempati $80 \%$ luas daratan Papua (416.000 $\mathrm{km} 2$ ) sebagai habitat aslinya bersama fauna mamalia lainnya. Kanguru hidup di arboreal dari permukaan laut sampai daerah hutan pegunungan tinggi sekitar $4000 \mathrm{~m}$, dengan kisaran suhu 100C - 27,040C dan kelembaban $78,5 \% \quad-86,5 \% \quad$ (Petocz, 1994 dan Yepasedanya, 2003). Khusus di Papua Barat kanguru pohon dapat dijumpai di Manokwari, Bintuni, Sorong, Sorong Selatan, Maybrat, Waigeo, Fak-fak, Kaimana, Wondama/Wasior dan Raja Ampat (Petocz, 1994). Kanguru di alam lebih menyukai dedaunan/pucuk muda, buah dan batang lunak dari ficus sp, Gnetum gnemon, Schuur mansia heningsii, Tetracera, Elastotema dan Procris serta rumput-rumputan dan beberapa tumbuhan menjalar (Flannery, 1995).

\section{Morfologi dan Biologi Kanguru Pohon (Dendrolagus sp)}

Kanguru masuk dalam keluarga
Macropodidae
yang paling khusus, yakni kantung (Anonimous, 2006). Lebih lanjut dijelaskan, kantung ini dapat membuka ke depan saat berkembang biak dan memiliki empat kelenjar susu, Kanguru Pohon gemar menghabiskan waktu di tanah. Petocz (1994) menyatakan Kanguru Pohon suka berteduh di bawah rimbun pohon-pohon besar. Bertungkai panjang dan mempunyai jari tengah panjang pada setiap tungkai belakang sehingga Kanguru Pohon mampu "berjalan-jalan" di cabang pohon dan bergerak dengan keempat tungkai pada waktu berjalan di atas tanah, namun bila terburu-buru, satwa ini kembali ke cara jalan melompat seperti kerabat lainnya. Tungkai depan dan belakang dari Kanguru Pohon yang hidup di hutan primer ini berukuran sama panjang. Tungkai belakang dan ekor kuat, tungkai depan kuat dan kontruksinya tipis, lebih ringan dan mudah digerakkan sering dipakai untuk memasukkan makanan ke dalam mulut (Petocz, 1994).

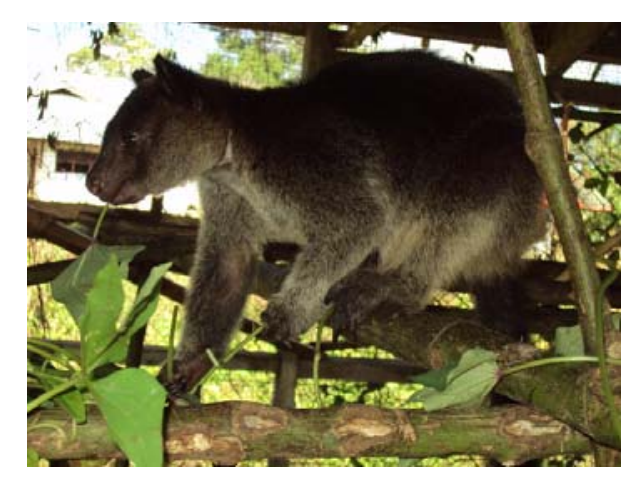

Gambar 1. Kanguru Pohon Kelabu (Dendrolagus inustus)

Kanguru Pohon umumnya memiliki kaki panjang dan memiliki empat jari. Jari kedua dan ketiga kecil sekali, satu sama lain bersambung dengan kulit kecuali pada ujungnya. Kanguru Pohon memiliki cakar khusus, berbentuk melengkung berfungsi untuk memanjat. Bila kulit batang pohon itu licin atau berdiameter besar, vegetarian taat ini tak sanggup menaikinya. Kanguru Pohon hanya dapat memanjat jika kulit batang pohon beralur-alur atau banyak terdapat tumbuhan merambat sebagai pegangan pada waktu naik. Kesulitan lain terjadi saat Kanguru Pohon ini menuruni cabang pohon yang terjal dan harus melakukannya secara tegak menghadap ke atas. Sebab bila menghadap ke bawah satwa yang pertama kali dicatat oleh Muller pada tahun 1840 ini tak memiliki pegangan kuat.

Telinganya panjang dan bagian dalam tak berambut. Ekor lebih panjang dari tubuh yang kadang-kadang berjumbai di ujungnya dengan pangkal polos dan kapalan. Lengan 
otot-ototnya kuat, pada Kanguru besar ekornya kuat, berfungsi menjaga keseimbangan tubuh juga sebagai penopang untuk duduk dan berkelahi. (Anonimous, 2009). Memiliki tekstur daging yang alot dan berongga.

Kanguru di alam, cenderung hidup secara berkelompok (sosial), yang disebut 'gerombolan' (mob) dengan satu jantan yang dominan, walaupun ada beberapa yang memilih hidup secara individu (soliter) (Petocz, 1994). Kanguru jantan yang dominan dalam tiap kelompok yang ada berhak menjaga dan mengawini semua betina yang ada dalam kelompok tersebut, secara temporer. Artinya ketika ada jantan lain yang dapat mengalahkannya maka jantan tersebutlah yang kemudian mewarisi hak dominan kelompok Kanguru ini (Anonimous, 2005 ${ }^{\mathrm{a}}$ ).

Rata-rata masa hidup seekor Kanguru berkisar antara 12 hingga 18 tahun Anonimous (2008). Panjang tubuh Kanguru Pohon antara $500-800 \mathrm{~mm}$, belum termasuk ekor. Untuk jenis dewasa dapat berbobot sekitar $6-18 \mathrm{~kg}$ (Flassy, 2007). Kanguru Pohon bereproduksi sepanjang tahun, betina Kanguru Pohon mengalami kematangan seks setelah mencapai berat badan $8,5-10 \mathrm{~kg}$ sedangkan jantan $12 \mathrm{~kg}$ (Flannery, 1995). Kanguru Pohon betina mempunyai kantung dengan lubang yang mengarah ke depan tempat puting dan kelenjar-kelenjar susu (Anonimous, 1989), rata-rata panjang dan diameter keempat putting susu adalah $(7 ; 0,94 ; 1,9 ; 2,9 \mathrm{~cm}$ dan 1,$4 ; 6 ; 6 ; 8,2 \mathrm{~mm}$ ) (Koibur, 2011)

Kanguru mengalami proses dipouse embrio atau kelahiran tertunda. Hal ini memungkinkan betina untuk kawin lagi setelah melahirkan atau waktu di dalam
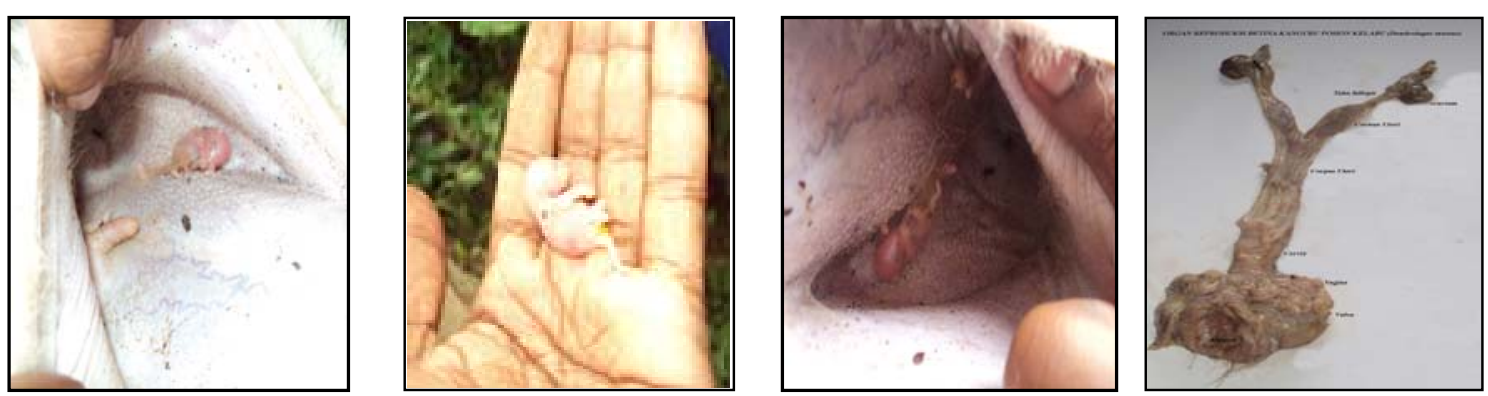

Gambar 2. Kantong, Organ Reproduksi Betina, Bobot Lahir dan Perkembangan Embrio Dalam kantung masih ada anak. Perkembangan telur yang telah dibuahi itu ditunda sampai anak itu hampir mengakhiri kehidupan dalam kantung, mati atau ditinggalkan. Penjadwalan waktu kelahiran ini membuat betina dewasa jarang bahkan tidak pernah tanpa anak dalam kantungnya (King, 2001). Gambar 2.

Kanguru pohon betina memiliki saluran reproduksi ganda secara lengkap (ovarium, tuba fallopi, cornu dan corpus uteri, cervix, vagina, vulva dan clitoris), dan jantan memiliki 2 gland penis sehingga penisnya berbentuk garpu. Seekor betina mampu menghasilkan 4 anak sepanjang tahun dengan umur yang berbeda. Gambar 2 .

Bobot lahir anak 200-400mg dengan panjang tubuh $3 \mathrm{~cm}$ (Koibur, 2011), dalam setahun ada kemungkinan seekor Kanguru memiliki empat anak yang berada dalam tahap perkembangan yang berbeda-beda dan bergantung pada induknya, masing-masing mendapatkan jenis air susu yang berbeda sesuai dengan tahap perkembangannya. Gambar 2.

Pada awal perkembangannya, anak mendapatkan susu yang bening dan tidak berwarna, kemudian susu berubah putih seperti air susu pada umumnya. Jumlah lemak dan zat kandungan lain juga bertambah sejalan dengan perkembangan anak (Anonimous, 2008). Keempat puting memberikan zat makanan dalam jumlah yang berbeda bagi ketiga anak Kanguru pada fase umur yang berbeda pula (Renfree, 2000). Gambar 2.

Sifat reproduksi Kanguru dari berbagai hasil penelitian disajikan dalam Tabel 1 .

\section{Kantong Kanguru Pohon Kelabu (Dendrolagus inustus)}


Tabel 1. Sifat-sifat reproduksi Kanguru

\begin{tabular}{|c|c|c|}
\hline Uraian & Karakteristik & Sumber (Pustaka) \\
\hline \multirow[t]{5}{*}{ Tanda-tanda berahi } & Gelisah mengeluarkan suara khas & Yepasedanya (2003) \\
\hline & Urine dan kloaka keluar cairan & Anonimous $(2005)^{b}$ \\
\hline & $\begin{array}{l}\text { khas yang menjadi indikator bagi } \\
\text { jantan }\end{array}$ & \\
\hline & $\begin{array}{l}\text { Jantan membelai dada betina, } \\
\text { betina menggerak-gerakan }\end{array}$ & Anonimous (2003) \\
\hline & $\begin{array}{l}\text { kepala/leher/ekor dan jantan } \\
\text { mengeluarkan suara berdecak }\end{array}$ & \\
\hline Periode kawin & Sepanjang tahun & \\
\hline \multirow[t]{2}{*}{ Lama bunting } & 31-36 hari & Anonimous (2008) \\
\hline & 33 hari & Anonimous $\left(2010^{\mathrm{b}}\right)$ \\
\hline Jumlah anak/kelahiran & 1 ekor & \\
\hline Umur sapih & 190 hari & Anonimous $\left(2005^{c}\right)$ \\
\hline Umur pubertas & ऽ20-24 bulan $\&$ $915-20$ bulan & Anonimous $\left(2005^{c}\right)$ \\
\hline Jarak kelahiran & 90 hari & King (2001) \\
\hline \multirow[t]{2}{*}{ Berat lahir } & $750 \mathrm{mg}$ & Anonimous $\left(2005^{c}\right)$ \\
\hline & $1 \mathrm{gr}$ & King (2001) \\
\hline Pejantan dewasa & 2,5 Tahun & Anonimous $\left(2005^{\mathrm{c}}\right)$ \\
\hline Betina dewasa & 2 Tahun & Anonimous $\left(2005^{c}\right)$ \\
\hline Beranak pertama kali & 18 Bulan & Anonimous $\left(2005^{c}\right)$ \\
\hline \multirow[t]{2}{*}{ Siklus berahi } & $58,9 \pm 2,4$ hari & Anonimous $\left(2005^{\mathrm{a}}\right)$ \\
\hline & 22-44 hari & King (2001) \\
\hline Lama berahi & 24-48 jam & King (2001) \\
\hline Lama hidup & 12-18 tahun & Flannery (1995) \\
\hline
\end{tabular}

\section{Pemanfaatan Kanguru Pohon Oleh Masyarakat Papua}

Masyarakat Papua khususnya mereka yang hidup di sekitar habitat asli kanguru pohon biasa berburu kanguru untuk dikonsumsi sebagai sumber protein hewani keluarga, dijual dalam kondisi hidup/mati (offsetan), dengan harga berkisar Rp. 500.000,- - 1.000.000,- dan untuk dipelihara sebagai hewan kesayangan. Perburuan yang dilakukanpun secara bijaksana dan hati-hati untuk tetap memelihara keberlangsungan hidup fauna tersebut sehingga kebutuhan mereka pun tetap terpenuhi setiap saat ketika dibutuhkan (Koibur, 2006).

Bagian kanguru yang dikonsumsi oleh masyarakat adalah dagingnya, yang diolah secara sederhana, yakni diasap/dipanggang, akan tetapi daging kanguru sebagaimana daging ternak umumnya dapat diolah juga menjadi berbagai aneka jenis makanan seperti sate, gulai, soto, dendeng, dll. Sebenarnya kulit/bulu kanguru pohon juga dapat dimanfaatkan untuk bahan baku tas, sepatu, dompet, jaket dan bahan baku tekstil lainnya, namun dibutuhkan penelitian lebih lanjut untuk kepastiannya

\section{Perkembangan Penangkaran Kanguru Pohon di Papua Barat}

Upaya penangkaran yang sudah dilakukan di Papua Barat antara lain : Yepasedanya (2003) bentuk persegi dengan bahan baku penangkaran berupa kayu buah seluas $4 \times 4 \times 4$ berisikan 4 ekor kanguru (1 jantan : 3 betina); Gombo (2004) merujuk pada Yepasedanya 2003 dan Koibur (2011) dengan bahan baku penangkaran kawat ram dan kayu balok lantai tanah berukuran $5 \times 5 \times 5$ berisikan 5 ekor kanguru (1 jantan : 4 betina). Penangkaran yang dilakukan dalam kaitan dengan riset untuk penyelesaian studi.

Yepasedanya (2003) menyatakan bahwa satwa ini dapat hidup dan berkembang biak di 
luar habitat aslinya. Lebih lanjut dilaporkan Kanguru Pohon memiliki kemampuan beradaptasi dengan lingkungan barunya serta dapat melakukan aktivitas kesehariannya seperti makan, minum, istirahat, bermain dan reproduksi sebagaimana kebiasaannya di alam selama 24 jam.

Kanguru dapat hidup dan mengalami pertumbuhan serta beraktivitas sebagaimana seperti di alam dalam penangkaran dengan mengkonsumsi daun dan batang kangkung (Ipomea aquatica), daun ubi jalar (Ipomea batatas), buah pisang (Musa paradisiaca), pepaya (Carica papaya) (Yepasedanya, 2003 dan Gombo, 2004) serta nasi dan papeda (Koibur, 2011). Kanguru lebih memilih mengkonsumsi daun ubi jalar dan kangkung di penangkaran (Gombo, 2004). Kanguru dapat mencapai $\mathrm{PBB} 0,9 \mathrm{~kg}$ dengan $\mathrm{PBBH} 0,03 \mathrm{~kg}$ selama 30 hari dalam penangkaran dengan pemberian pakan sederhana tanpa melihat kualitas (Yepasedanya, 2003 dan Gombo, 2004)

\section{KESIMPULAN}

Kanguru pohon adalah satwa mamalia marsupialia endemic Papua yang berhabitat di sebagian besar hutan primer Papua. Kanguru pohon dapat ditangkarkan dan berpeluang menjadi ternak harapan penghasil daging, bulu dan kulit di masa mendatang. Papua Barat berpotensi mengembangkan kanguru pohon menjadi ternak unggulan

\section{DAFTAR PUSTAKA}

Anonimous. 1989. Ensiklopedia Mamalia. Balai Pustaka. Jakarta

, 2003. Kangaroos Behavior. Diakses dari : http://sissonce.tripod.com. Tanggal 12-10-2010

L 2005. Reproduction Kangaroo. Diakses dari : http://encarta.msn.com. Tanggal 10-4-2009

2005 ${ }^{\mathrm{b}}$. Red Kangaroo (Macropus rufus). Diakses dari : www.saczoo.com. Tanggal 1010-2010

$-2005^{\mathrm{c}}$. Reproduction Kangaroo. Diakses dari : http://planet.uwc.ac.za. Tanggal 20-10-2010
2006. Kangaroo. Diakses dari : http://en.wikipedia.org/wiki/Kangaroo. Tanggal 10-4-2009

,2008. Kangaroo Reproduction Diakses dari: $\quad$ www.kangaroolearningzone.com. Tanggal 18-10-2010

, 2009. Kanguru Pohon, Sisa Australia di Papua. Diakses dari : http://dydear.multiply.com/journal.

Tanggal 01-07-2009 , 2010 a . Kangguru Tokoh Dalam Kisah Kelahiran yang Luar Biasa. Diakses dari imanamamizar.blogspot.com. Tanggal 10-10-1010 2010 . Red Kangaroo Reproduction System. Diakses dari : http://www.scribd.com/Red-KangarooReproductive-System. Tanggal 20-102010

Flannery, T. 1995. Mamals Of New Guinea. Australian Museum.

Flassy D. A., 2007. Fauna Tanah Kita untuk Pengenalan di Sekolah dan Pengetahuan Umum. Balai Pustaka. Jakarta

Gombo H., 2004. Tingkat Kesukaan Kanguru Pohon Kelabu Terhadap Beberapa Jenis Pakan Dalam Penangkaran di Kampung Famboaman Distrik Yapen Selatan Kabupaten Yapen Waropen. Skripsi Sarjana Peternakan FPPK UNIPA. Manokwari.

King A., 2001. Discoveries about Marsupial Reproduction. Diakses dari : www.biology.iastate.edu. Tanggal 12-42009

Koibur, J.F., 2006. Perburuan Kanguru Pohon Kelabu (Dendrolagus inustus) dan Pemanfaatannya Oleh Masyarakat Angkaisera Di Yapen Papua. Laporan Penelitian Dosen Muda Dirjen Dikti Jakarta.

，2011. Karakteristik dan Organ Reproduksi Kanguru Pohon Kelabu (Dendrolagus inustus) Di Papua. Tesis Pascasarjana Universitas Gadjah Mada. Yogyakarta.

Petocz, R. G., 1994. Mamalia Darat Irian Jaya. Gramedia. Jakarta. 
Renfree M.B. and G. Shaw, 2002. Reproduction of a marsupial: From uterus to pouch. Animal Reproduction Science, Vol. 64, Issue 1

Yepasedanya, S., 2003. Tingkah Laku Harian Kanguru Pohon Kelabu (Dendrolagus inustus) Dalam Penangkaran di Kampung Famboaman Distrik Yapen Selatan Kabupaten Yapen waropen. Skripsi Sarjana Peternakan FPPK UNIPA. Manokwari. 